\title{
Articles
}

\section{Assistant Foreign Language Teachers in Japanese High Schools: Focus on the Hosting of Japanese Teachers}

\section{Greta Gorsuch \\ Texas Tech University}

For both political and social reasons, the learning of English as a Foreign Language in Japanese secondary schools has become the focus of a variety of new educational policies applied at a national level. The backdrop of this article is the JET program, which in 1998 employed 5,361 assistant language teachers (ALTs) from various countries for the purpose of team teaching in Japanese junior and senior high school foreign language classrooms. The article focuses on Japanese teachers of English (JTEs) and their responses to team teaching with ALTs, particularly in terms of JTEs' perceptions of their own English speaking skills and English language learning experiences. Drawing from the questionnaire responses of $884 \mathrm{JTEs}$ in high schools in nine randomly selected prefectures, the author also outlines patterns in assignment of ALTs in both academic and vocational high schools, providing a more complete picture of the JET program.

日本の高校における外国語としての英語教育は、政治的、社会的な理由によ り、全国規模で新たな教育政策の流れに組み込まれようとしている。本稿は、 1998年に中学・高等学校の外国語クラスにティームティーチングの一員として 様々な国から雇い入れられた5,361名のJETプログラムの語学助手（ALT）の扱 いを取り上げ、日本人英語教師 (JTE) の、ALTとのティームティーチングにお ける反応、特にJTEが自身の英語の話し方能力と英語学習経験についてどのよ うに考えているのかを検証する。任意に選んだ 9 つの県の中・高校で教える 884 人の JTE の質問用紙への回答から、進学校と商業高校の両方で、ALTが どのような仕事を割り当てられているのかを明らかにし、JETプログラムの全 体像が解明できることを目指した。 
$\mathrm{F}$ or both political and social reasons, the learning of English as a Foreign Language in Japanese secondary schools has become the focus of a variety of new educational policies applied at a national level in Japan. Among these has been the Japan Exchange and Teaching (JET) program, started in 1987, which has brought native English speaking "assistant language teachers" (ALTs) into Japanese junior and senior high school English classes (McConnell, 1995; Wada \& Cominos, 1994). The overt purpose of the JET program is to have the ALTs and Japanese teachers of English (JTEs) interact in English, raise JTEs' awareness of English as a communicative medium, and promote communicative English teaching in the classroom (Wada \& Cominos, 1994, p. 1). As such, the JET program offers a powerful potential for instructional change among Japanese teachers of English. The JET program is well endowed, with an annual operating budget of US\$222,000,000 (McConnell, 1995), and employs 5,361 ALTs from numerous countries ("JET program," 1998).

In 1989, the Ministry of Education issued a new set of curriculum guidelines and course descriptions for the instruction of English in high schools, called The Course of Study (Ministry of Education, Science, and Culture, 1992). The Course of Study was intended to promote development of students' communicative skills (Council on the School Curriculum, in Wada, 1994, p. 9). In high schools, the objectives of the two required mainstay four-skills English courses, English I and English II, were written to include guidelines to be used to promote students' listening and speaking abilities, and to instill a "positive attitude towards communicating in English" in high school students (Ministry of Education, Culture, \& Science, 1992, p. 3). This was the first time, in the course of many periodically issued national curriculum guidelines for foreign languages, that "communication" was named as a goal of instruction. Explicit mention was made in The Course of Study that JTEs should use team teaching activities, which implies the presence and cooperation of ALTs.

Given the conservative leanings of the Japanese education sector (Lincicome, 1993), the JET program, along with the new Course of Study, represent radical policies applied on a national level. However, there are several obvious aspects of the Japanese high school educational culture that work against JTEs' acceptance of classroom activities designed to promote students' communicative abilities (McConnell, 1995; see also Gorsuch, 2001, who cites the prevalence of non-communicative pedagogies and university entrance exams, as well as inadequate teacher preparation and in-service programs). These aspects of Japanese education imply a mismatch between the official plan and the realities of Japanese high school EFL education. 
As the local implementers of the JET program, JTEs are major stakeholders in this ambitious educational policy. Nevertheless, the potential effects of ALTs on JTEs, who are often entrusted with the supervision of ALTs and the team teaching process, do not seem to have been explored on a large scale. Specifically, this study focused on comparing teachers who taught English I or II regularly with ALTs with teachers who had zero or had limited ALT contact in their English I or II classes. Using a Japanese-language survey, 884 teachers from these three groups were asked to provide ratings on their own classroom English speaking ability, self-reports of early English learning experiences, and attitudes towards teaching activities associated with communicative language teaching, audiolingualism, and yakudoku (a traditional Japanese grammar-translation methodology).

\section{Construction of the Survey}

\section{Accounting for Two Influences}

Frameworks for investigating the effects of governance on teachers' instruction provided an important way of organizing the collection of data of the survey. In the literature, influences on classroom instruction are classified into what can best be termed formal influences and informal influences (Cohen \& Spillane, 1992; Fuller, Snyder, Chapman, \& Hua 1994; Montero-Sieburth, 1992; Stevenson \& Baker, 1991). See Table 1 for a summary of formal and informal instructional guidance.

Two of the categories in Table 1 were used to create the survey items of interest in this report: teachers' foreign language proficiency and teachers' previous educational experiences. Items created from other categories in Table 1 were also included in the survey, but are beyond the scope of this report.

\section{Teachers' English Proficiency}

Historically, teachers have not needed to be proficient to teach English in Japanese high schools. After World War II, procedures for high school teacher certification were greatly liberalized. One of the reasons for this was an increased demand for English teachers after the end of the war (Henrichsen, 1989, p. 126). Another reason, according to Shimahara (1995), was to nullify rigid pre-war teacher education traditions, which were seen as a tool by militarists to gain control over schools and students. The idea was to open teacher certification to graduates of liberal arts universities who would be less swayed by authoritarian ideals. Thus, students getting degrees in English literature could get an English teacher's 
certificate by simply completing the requirements. However, according to Henrichsen (1989, p. 126), this led to the hiring of teachers who were not particularly knowledgeable of English. In addition to English literature majors who had probably never had to speak English in their university courses, graduates who had majored "in some subject other than English but had received passing marks in their English classes... were put into English-teaching positions" (p. 162, emphasis in the original). This helped to create teachers who had studied English in the written mode and who then neglected oral/aural skills (Henrichsen, 1989). The implementation of the JET program may be changing that, at least for JTEs who have contact with ALTs. In the survey used to generate data for this report, teachers were asked to gauge their level of agreement to the statement: "My English speaking ability is good enough for me to use in class." A response of "1" meant strong disagreement, while a "5" meant strong agreement, and "3" meant "I don't know."

\section{Table 1: Formal and Informal Influences on Teachers' Instruction}

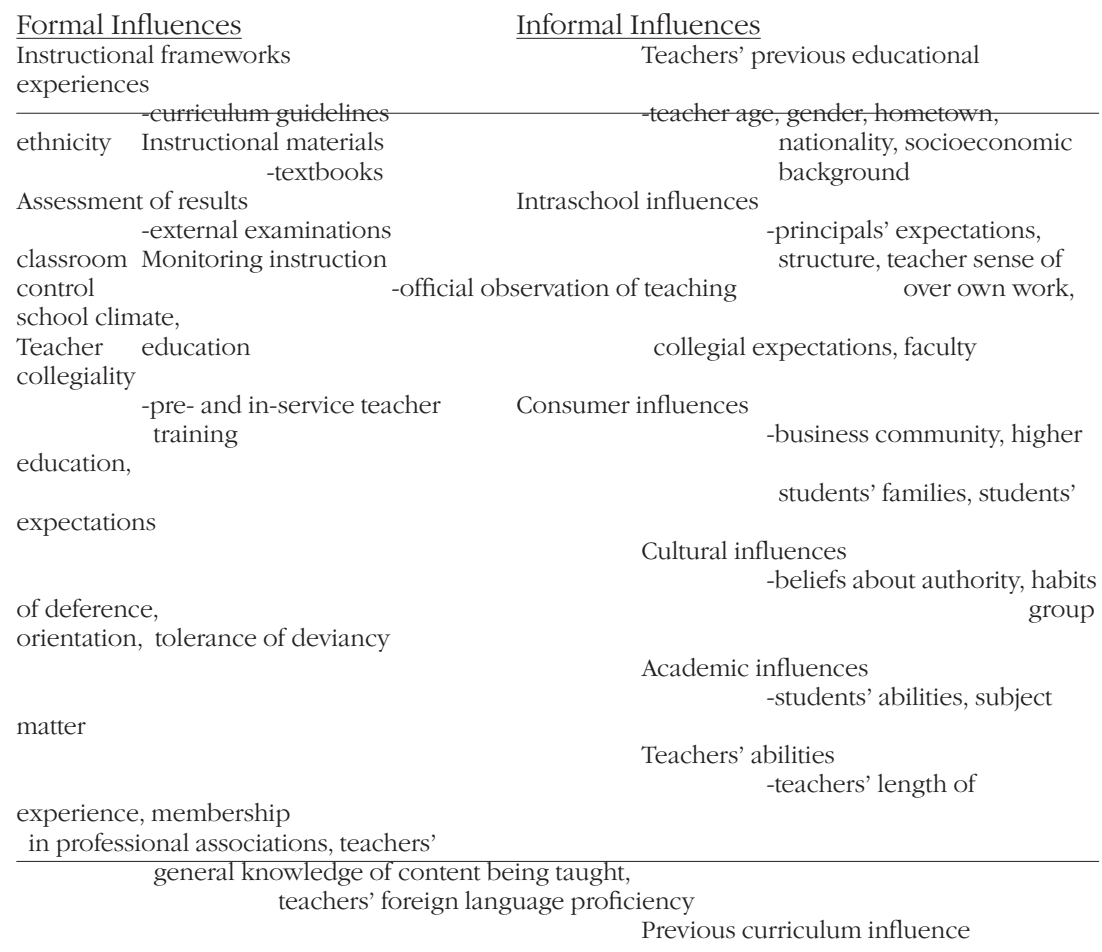

Note: Categories adapted from Cohen and Spillane (1992); Fuller, Snyder, Chapman, and Hua (1994); Montero-Sieburth (1992); and Stevenson and Baker (1991). 


\section{Previous Educational Experiences}

Cohen and Spillane (1992) suggested that of all the influences that can be accounted for, teachers' previous educational experiences have the greatest influence on teachers' eventual instructional practices, going so far as to name elementary and secondary schools as the "prime agencies of teacher education" (p. 26). MacDonald and Rogan (1990) noted that South African science teachers involved in a science education reform project tended to employ teacher-to-whole-class lecture style instruction because they themselves were taught that way. In the end, no matter what educational policies are handed down, teachers' own long "apprenticeship" into teaching (their own educational experiences) (Lortie, 1975, p. 61) will continue to have lasting influence on teachers' instruction (Freeman \& Richards, 1993; Kennedy, 1989; Schmidt, Porter, Floden, Freeman, \& Schwille, 1987).

For the purposes of this discussion it will be assumed that most high school teachers learned English through yakudoku, a non-oral approach to foreign language instruction, thought to be related to grammar/translation (Bryant, 1956; Henrichsen, 1989; Hino, 1988; Law, 1995). A 1983 survey conducted by the Research Group for College English Teaching in Japan (in Hino, 1988, p. 46) reported that among its 1,012 Japanese university and high school teacher respondents nationwide, 70 to 80 percent used yakudoku in their EFL reading classes. Given this indirect evidence, it is likely that many current Japanese high school English teachers learned English through yakudoku as students. Further, two yakudoku high school teachers, aged around 40, reported to Gorsuch (1998) that they had learned English as high school students using yakudoku.

A brief description of yakudoku instructional practices as reported in Gorsuch (1998) will be given here. In three yakudoku English II classes taught at a boys' high school, Gorsuch observed that the students were required to process English texts by translating them into Japanese. The majority of class time was spent on teachers asking individual students to read their Japanese translations of an English sentence, or phrase, out loud. The teachers would then correct the student's Japanese translation, and then comment on the student's apparent misunderstanding of the grammar of the English text. The teachers would write the English grammar point on the board, and complete a lengthy explanation of the structure, often giving students advice on translating the grammar point into appropriate Japanese. The classes were teacher-centered, and conducted in Japanese.

It is not difficult to see the potential problems an ALT might have 
team teaching in such a classroom as described above. With the class being conducted almost entirely in Japanese by the JTE, a non-Japanese speaking ALT could not hope to contribute (ALTs hired by the JET program are either newcomers to Japan or may not have been residents in Japan for more than three years, so they may not achieve a high level of competence as Japanese speakers, according to Wada \& Cominos, 1994, p. 5). In addition, the goals of such classes clearly do not include improving students' skills in communicating in English. If in fact most JTEs learned English themselves using yakudoku, it may be unlikely that many JTEs can accommodate, without a struggle, changes in their teaching implied by the presence of an ALT in the classroom. Yet over 5,000 ALTs are currently teaching in Japanese junior and senior high schools, and a struggle is occurring in many JTEs' working lives (see Yukawa, 1992, 1994 for compelling accounts of this phenomenon). In our survey, teachers were asked to assess their level of agreement with the statement: "As a student I studied English primarily through translating English stories, essays, or literary works into Japanese." A response of " 1 " meant strong disagreement, while a " 5 " meant strong agreement, and "3" meant "I don't know."

\section{Attitudes towards CLT, ALM, and Yakudoku Activities}

The survey used for the larger study of which this report is a part, used five-point Likert scale items which invited teachers to respond affectively to a series of items representing activities associated with three different approaches to language learning: communicative language teaching (CLT), the audiolingual method (ALM), and yakudoku. Over 30 activities were gathered from teaching methodology books and courses and from observations of a variety of Japanese EFL classrooms. The activities were then presented to a panel of eight language educators who had at least a master's degree in TESL. Two were female native speakers of English, two were female native speakers of Japanese, two were male native speakers of English, and two were male native speakers of Japanese. The panel members then categorized each activity as CLT, ALM, or yakudoku. Only those activities which panelists unanimously categorized as one of the three types were included in a pilot questionnaire. The activity items were further revised in response to factor analyses of the pilot questionnaire. On the main questionnaire, higher scores of " 4 " or " 5 " indicated teachers' approval of the activities, while lower scores of "1" or "2" indicated disapproval of the activities, and " 3 " meant "I don't know." 


\section{Research Questions}

The overall purpose of this article is to report data from a survey of 884 Japanese high school EFL teachers in nine randomly selected prefectures. The first two research questions are:

1. According to the JTEs responding to the survey, what are the relative numbers of teachers who teach English I and II at least once a week with an ALT, less than once a week with an ALT, or not at all?

2. What are the patterns of distribution of ALTs team teaching in English I and II classes according to type of school?

These two questions have been included to address a lack of information in the literature concerning the number and distribution of ALTs in English I and II classes. There may be a mistaken perception on the part of researchers inside and outside Japan that ALTs are universally available to team teach with JTEs in Japanese EFL high school classrooms. The final three questions were raised in the literature review of this report. Do JTEs with different levels of ALT contact have different perceptions of themselves? Further, do they have different levels of approval for different kinds of activities, according to their level of ALT contact? Specifically:

3. Do JTEs' self-reports of English speaking ability differ according to their level of contact with ALTs in English I and II classes?

4. Do JTEs' self-reports of their own English learning experiences differ according to their level of contact with ALTs in English I and II classes?

5. DoJTEs' level of approval of communicative, ALM, and yakudoku activities differ according to level of contact with ALTs in English I and II classes?

\section{Method}

\section{Participants: Creating a Generalizable Sample}

The participants for this research were 884 Japanese senior high school EFL teachers currently employed full time at public academic, public vocational, and private academic senior high schools in Japan. Probability sampling procedures were followed (Fowler, 1993; Rea \& Parker, 1992, p. 147). The prefectures sampled were: Fukui, Kanagawa, Nagano, Saga, Shizuoka, Tokushima, Toyama, Yamagata, and Yama- 
guchi, all of which represent a variety of urban, rural, and geographic contexts.

Private high schools were included in the sample. Due to an exploding population from 1946 to 1980 and a restrictive national policy towards growth in public high school education, a substantial number of private high schools were established by 1980 , comprising $28.1 \%$ of all high schools in Japan (James \& Benjamin, 1988, p. 20). All primarily privately funded high schools were termed "private high schools." National, prefectural, and city-funded schools were termed "public high schools." There was no differentiation, for the purposes of this study, between all boys' and girls' schools, and coeducational schools.

Teachers at public vocational and night high schools were also included. While statistics for numbers of English teachers by type of school could not be found at the national level, combined teachers' lists for the nine prefectures surveyed in this study revealed that Japanese English teachers at public vocational and night high schools still constituted a sizable minority, 783 (13\%) of 6,167 teachers at public and private academic and public vocational and night high schools.

\section{Materials}

The Japanese-language questionnaire was developed according to results of a pilot questionnaire project of 500 Japanese EFL teachers in Tokyo in 1997, from previous research, and from an extensive literature review (see Gorsuch, 1999a). The theoretical background of the items of interest in this report is discussed in the literature review above. For the English-language version of the questionnaire, see Appendix A. Data that answered research question No. 1 came from item B-3. For research question No. 2, the data came from item B-2. For research question No. 3 , the data came from item C-1. To answer research question No. 4, data from item C-2 were examined. Finally, for research question No. 5, data from items A-1 through A-12 were examined.

The questionnaire was translated into Japanese by a highly English proficient Japanese female with teaching experience at the high school and university level. The Japanese version was then back-translated into English by a native English speaking professional translator who specializes in translating Japanese into English. Alpha reliability for items A-1 through A-12 was estimated at .71, which indicates moderate reliability. Reliability for items B-2, B-3, C-1, and C-2 was not estimated because they were designed to capture disparate constructs. 


\section{Analyses}

The numerical responses on the returned questionnaires were hand coded and entered by the researcher into Statview 4.5. To answer research question No. 1, teachers' responses to questionnaire item B-3 (level of involvement with an ALT in English I and II classes) were tabulated. For research question No. 2, teachers' responses to item B-3 were split by type of school (B-2). To determine whether the distribution of ALTs to the three different types of schools was meaningful and not simply a pattern occurring by chance, a chi-square procedure was conducted at $\mathrm{p}<.05$. To answer research question No. 3, descriptive statistics of teachers' responses to item C-1 (English speaking ability) were calculated, and were then split by the grouping variable B-3 (JTEs teaching English I and II with an ALT at least once a week, less than once a week, or not at all), resulting in three different mean scores. To determine whether the three resulting means were significantly different, an unbalanced one-way ANOVA procedure was conducted at $\mathrm{p}<$ .05. To determine whether the data met the assumptions of ANOVA, the data in each of the three cells were checked for normality and for equal variance (Hatch \& Lazaraton, 1991). In the event that the three means were found to be significantly different, the Scheffe test and eta ${ }^{2}$ strength of association were calculated to determine how much variance in the data could be attributed to the variable of interest (B-3, in this case). $\mathrm{Eta}^{2}$ was used because the cells of the ANOVA were unbalanced (Hatch \& Lazaraton, 1991, p. 331).

To answer research question No. 4, descriptive statistics of teachers' responses to item C-2 (teachers' English learning experiences) were calculated and then split by the grouping variable B-3 (teachers' reported level of involvement with an ALT in English I and II classes), again resulting in three different mean scores. To determine whether the means for the three groups were significantly different, a one-way, unbalanced ANOVA procedure was conducted at $\mathrm{p}<.05$. Normality and equivalence of variance for the three cells were checked, and the Scheffe test and eta ${ }^{2}$ strength of association were calculated. Finally, to answer research question No. 5, descriptive statistics for items A-1 through A-12 (teachers' level of approval of communicative, ALM, and yakudoku activities) were calculated and then split by the grouping variable B-3. Items A-1 through A-12 were twelve dependent variables, and $\mathrm{B}-3$ was the independent variable. To determine whether the means for the twelve items were significantly different, twelve separate oneway, unbalanced ANOVA procedures were conducted at $\mathrm{p}<.0042(.05$ divided by 12 for 12 comparisons; this was done to adjust for the multiple 
comparisons and avoid Type I error assuming a significant difference in means, when in fact the difference is not significant, see Vogt, 1999, pp. 28-29). Normality and equivalence of variance for the three cells of each dependent variable were checked, and the Scheffe test and eta ${ }^{2}$ strength of association were calculated.

\section{Results}

The numbers of JTEs responding to the survey who were categorized into three groups according to level of ALT contact in English I and II classes appear in Table 2.

Table 2: JTEs' Reported ALT Contact in English I and II Classes

\begin{tabular}{llc}
\hline Group & Number & Percent \\
\hline Teaches at least once a week with an ALT. & 179 & $20 \%$ \\
Teaches less than once a week with an ALT. & 167 & $19 \%$ \\
Does not teach with an ALT. & 538 & $61 \%$ \\
Total & 884 & $100 \%$ \\
\hline
\end{tabular}

Note: Percentages have been rounded.

The largest group of JTEs responding to this survey $(n=538$, or $61 \%$ of all respondents) reported that they did not teach English I and II with an ALT. The second largest group reported teaching with ALTs at least once a week ( $n=179$, or $20 \%$ ), and the smallest group reported teaching with ALTs less than once a week $(n=167$, or $19 \%)$.

The distribution of ALTs split by type of school (public academic, public vocational, and private academic) suggested that ALTs are not distributed equally. In Table 3, the observed (actual) frequencies are displayed along with expected frequencies (random frequencies that are predicted in chi square distributions, see Vogt, 1999, pp. 39-40). The chisquare statistic for the data was significant at $\mathrm{p}<.05$ (chi square $=123.067$, $\mathrm{df}=4$ ). This means that the patterns in the grouping of teachers in the actual data are significantly different from what a random pattern would suggest. For instance, private academic high school JTEs reported not teaching with ALTs in English I and II classes more than expected (229 compared with 159). Private academic high school JTEs also reported teaching with ALTs less than expected (26 compared with 
Table 3: Observed and Expected Frequencies for Distribution of ALTs in English I and II Classes by Type of School

\begin{tabular}{|c|c|c|c|c|}
\hline & \multicolumn{4}{|c|}{ Observed (Actual) Frequencies } \\
\hline & $\begin{array}{l}\text { Teach with } \\
\text { ALT at least } \\
\text { once a week. }\end{array}$ & $\begin{array}{l}\text { Teach with ALT } \\
\text { less than once } \\
\text { a week. }\end{array}$ & $\begin{array}{l}\text { Do not teach } \\
\text { with an ALT. }\end{array}$ & Total \\
\hline Public Academic Teachers & 72 & 91 & 179 & 342 \\
\hline Public Vocational Teachers & 81 & 70 & 130 & 281 \\
\hline Private Academic Teachers & 26 & 6 & 229 & 261 \\
\hline \multirow[t]{3}{*}{ Total } & 179 & 167 & 538 & 884 \\
\hline & \multicolumn{4}{|c|}{$\begin{array}{l}\text { Expected Frequencies } \\
\text { (frequencies which would occur by chance) }\end{array}$} \\
\hline & $\begin{array}{l}\text { Teach with } \\
\text { ALT at least } \\
\text { once a week. }\end{array}$ & $\begin{array}{l}\text { Teach with ALT } \\
\text { less than once } \\
\text { a week. }\end{array}$ & $\begin{array}{l}\text { Do not teach } \\
\text { with an ALT. }\end{array}$ & Total \\
\hline Public Academic Teachers & 69 & 65 & 208 & 342 \\
\hline Public Vocational Teachers & 57 & 53 & 171 & 281 \\
\hline Private Academic Teachers & 53 & 49 & 159 & 261 \\
\hline Total & 179 & 167 & 538 & 884 \\
\hline
\end{tabular}

Note: Numbers have been rounded.

53, and 6 compared with 49). ALTs are apparently not assigned toteam teach with JTEs in English I and II classes in private academic high schools very often. JTEs at public academic high schools reported teaching with an ALT more than expected ( 72 compared with 69, and 91 compared with 65), and not teaching with ALTs less than expected (179 compared with 208). Public vocational JTEs reported teaching English I and II with ALTs more than expected (81 compared with 57, and 70 compared with 53). In addition, they reported not teaching with an ALT fewer times than expected (130 compared with 171). Public academic and vocational high schools apparently assign ALTs to team-teach English I and II classes more than random chance would suggest. 
Table 4 shows the descriptive statistics for item C-1 (teachers' ratings of their English speaking ability) split by the grouping variable B-3 (level of involvement with an ALT in English I and II classes).

Table 4: JTEs' Self-Reports of English Speaking Ability

\begin{tabular}{lrrrrrr}
\hline & \multirow{2}{*}{ M } & SD & Min/Max & \multicolumn{2}{l}{ Skew } \\
\cline { 2 - 7 } Kurtosis & & & & & & \\
& & & & & \\
Teaches English I or II with an ALT at least once a week & 3.520 & .887 & $1 / 5$ & -.300 & -.271 \\
Teaches English I or II with an ALT less than once a week 3.126 & .856 & $1 / 5$ & .100 & -.188 \\
Does not teach English I or II with an ALT & 3.102 & .889 & $1 / 5$ & -.027 & -.608 \\
Total & 3.191 & .898 & $1 / 5$ & -.047 & -.517
\end{tabular}

Note: A rating of "5" indicates strong agreement with the statement: "My English speaking ability is good enough for me to use in class," and " 1 " indicates strong disagreement.

Teachers who reported teaching with ALTs at least once a week had a higher mean score (3.520), indicating a higher self rating of their English ability as used in class. Teachers who reported teaching with ALTs less than once a week or not at all had lower mean scores (3.126 and 3.102, respectively). The difference in means was statistically significant at $\mathrm{p}<.05(\mathrm{~F}=15.532, \mathrm{df}=2)$. A post hoc Scheffe test indicated that the mean score of teachers teaching with ALTs at least once a week was significantly higher than the mean for teachers teaching less than a week with an ALT, or not teaching with an ALT. However, the eta $^{2}$ statistic indicated that only .046 (4.6\%) of the variance in the three mean scores was due to the ALT contact variable. This may be due to the presence of other variables in the data, for example JTEs' type of school, length of career, or perhaps intra-school politics or collegial attitudes. Some respondents may have also been unwilling to answer the question, which may have resulted in systematically lower or higher self-estimates, depending on other personal variables not captured by the questionnaire (Gorsuch, 2000).

Table 5 shows the descriptive statistics for item C-2 (teachers' agreement that they had learned English through yakudoku) split by the grouping variable B-3 (level of involvement with an ALT in English I and II classes). 
Table 5: JTEs' Self-Reports of English

Language Learning Experiences

\begin{tabular}{lrrrrrr}
\hline & M & SD & Min/Max & \multicolumn{2}{l}{ Skew } \\
\cline { 2 - 7 } Kurtosis & & & & & & \\
& & & & & & \\
Teaches English I or II with an ALT at least once a week & 3.291 & 1.106 & $1 / 5$ & -.368 & -.678 \\
Teaches English I or II with an ALT less than once a week 3.545 & 1.104 & $1 / 5$ & .608 & -.362 \\
Does not teach English I or II with an ALT & 3.414 & 1.175 & $1 / 5$ & -.496 & -.714 \\
Total & 3.414 & 1.151 & $1 / 5$ & -.489 & -657 \\
\hline
\end{tabular}

Note: A rating of " 5 " indicates strong agreement with the statement: "As a student I studied English primarily through translating English stories, essays, or literary works into Japanese," and "1" indicates strong disagreement.

The results of the data suggested that JTEs with extensive contact with ALTs had a lower level of agreement with the notion that they had studied English through traditional grammar-translation methods (3.291) than JTEs with limited (3.545) or no ALT contact (3.414). However, a one-way ANOVA with the p value set at .05 indicated that the differences between the means were not statistically significant.

The descriptive statistics for items A-1 through A-12 (JTEs' approval of CLT, ALM, and yakudoku activities) split by the grouping variable B-3 (level of involvement with an ALT in English I and II classes) are in Table 6.

Table 6: Descriptive Statistics for Activities Items Split by Level of Involvement with an ALT

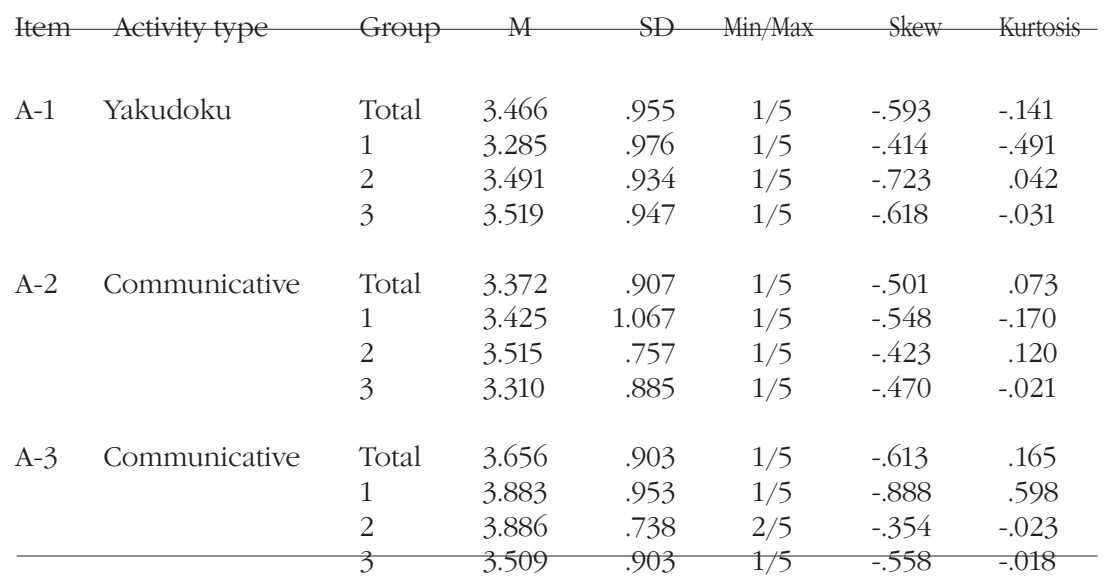


Table 6 (Continued)

\begin{tabular}{|c|c|c|c|c|c|c|c|}
\hline ftem & Activity type & Group & M & SD & Min/Max & Skew & Kurtosis \\
\hline \multirow[t]{4}{*}{ A-4 } & Yakudoku & Total & 3.084 & 1.068 & $1 / 5$ & -.295 & -.735 \\
\hline & & 1 & 2.922 & 1.070 & $1 / 5$ & -.200 & -.729 \\
\hline & & 2 & 3.072 & 1.012 & $1 / 5$ & -.109 & -.718 \\
\hline & & 3 & 3.141 & 1.078 & $1 / 5$ & -.381 & -.724 \\
\hline \multirow[t]{4}{*}{ A-5 } & Audiolingual & Total & 3.769 & .849 & $1 / 5$ & -.807 & .825 \\
\hline & & 1 & 3.726 & .844 & $1 / 5$ & -.674 & .730 \\
\hline & & 2 & 3.677 & .857 & $1 / 5$ & -.643 & .314 \\
\hline & & 3 & 3.812 & .845 & $1 / 5$ & -.910 & 1.084 \\
\hline \multirow[t]{4}{*}{ A-6 } & Audiolingual & Total & 3.615 & .807 & $1 / 5$ & -.578 & -.008 \\
\hline & & 1 & 3.508 & .912 & $1 / 5$ & -.379 & -.598 \\
\hline & & 2 & 3.611 & .749 & $2 / 5$ & -.595 & -.014 \\
\hline & & 3 & 3.652 & .783 & $1 / 5$ & -.628 & .232 \\
\hline \multirow[t]{4}{*}{ A-7 } & Communicative & Total & 3.361 & .890 & $1 / 5$ & -.386 & -.271 \\
\hline & & 1 & 3.441 & .928 & $1 / 5$ & -.479 & -.265 \\
\hline & & 2 & 3.419 & .891 & $1 / 5$ & -.365 & -.445 \\
\hline & & 3 & 3.316 & .873 & $1 / 5$ & -.374 & -.206 \\
\hline \multirow[t]{4}{*}{ A-8 } & Audiolingual & Total & 3.572 & .836 & $1 / 5$ & -.583 & .274 \\
\hline & & 1 & 3.626 & .852 & $1 / 5$ & -.774 & .796 \\
\hline & & 2 & 3.623 & .809 & $1 / 5$ & -.706 & .557 \\
\hline & & 3 & 3.539 & .838 & $1 / 5$ & -.484 & .048 \\
\hline \multirow[t]{4}{*}{ A-9 } & Communicative & Total & 3.376 & .945 & $1 / 5$ & -.351 & -.329 \\
\hline & & 1 & 3.497 & 1.005 & $1 / 5$ & -.521 & -.293 \\
\hline & & 2 & 3.383 & .914 & $1 / 5$ & -.218 & -.768 \\
\hline & & 3 & 3.333 & .930 & $1 / 5$ & -.345 & -.199 \\
\hline \multirow[t]{4}{*}{ A-10 } & Yakudoku & Total & 3.542 & .829 & $1 / 5$ & -.824 & .585 \\
\hline & & 1 & 3.508 & .855 & $1 / 5$ & -.805 & .656 \\
\hline & & 2 & 3.581 & .776 & $1 / 5$ & -.654 & .247 \\
\hline & & 3 & 3.541 & .836 & $1 / 5$ & -.865 & .587 \\
\hline \multirow[t]{4}{*}{ A-11 } & Communicative & Total & 3.888 & .738 & $1 / 5$ & -1.034 & 2.404 \\
\hline & & 1 & 3.911 & .757 & $1 / 5$ & -1.164 & 3.240 \\
\hline & & 2 & 3.964 & .656 & $2 / 5$ & -.218 & .045 \\
\hline & & 3 & 3.857 & .754 & $1 / 5$ & -1.136 & 2.362 \\
\hline \multirow[t]{4}{*}{ A-12 } & Communicative & Total & 3.890 & .766 & $1 / 5$ & -1.172 & 2.525 \\
\hline & & 1 & 3.872 & .755 & $1 / 5$ & -1.107 & 2.209 \\
\hline & & 2 & 3.916 & .669 & $2 / 5$ & -.501 & .711 \\
\hline & & 3 & 3.888 & .796 & $1 / 5$ & -1.299 & 2.750 \\
\hline
\end{tabular}

Note: Group 1 = teachers teaching with ALTs at least once a week; Group 2 = teachers teaching with ALTs less than once a week; Group 3 = teachers not teaching with ALTs. 
Twelve ANOVA procedures were carried out, each with the p value set at .0042. Only one item, A-3, a CLT information gap item calling on students to speak and listen, was significant at $\mathrm{p}<.0042(\mathrm{~F}=18.865, \mathrm{df}=$ 2). A post hoc Scheffe test indicated that teachers teaching with an ALT at least once a week (3.883) and less than once a week (3.886) were more approving of the CLT activity than teachers with no ALT contact (3.509). Eta ${ }^{2}$ was estimated at .057 , which indicated that $5.7 \%$ of the variance between the three mean scores on A-3 were due to the ALT contact variable. As with the data displayed in Table 4, this may be due to the presence of other variables in the data.

Two other items, A-1 (a yakudoku activity, $\mathrm{p}=.0166$ ) and A-2 (a CLT reading activity, $\mathrm{p}=.0267)$, approached significance, but did not exceed the predesignated $\mathrm{p}<.0042$. On A-1, teachers with no ALT contact (3.519) were more approving of a yakudoku activity than JTEs teaching with an ALT at least once a week (3.285). On A-2, JTEs teaching with an ALT less than once a week (3.515) were more approving of a CLT reading activity than teachers with no ALT contact (3.310).

\section{Discussion}

To restate the first research question: According to the JTEs responding to the survey, what are the relative numbers of teachers who teach English I and II at least once a week with an ALT, less than once a week with an ALT, or not at all? A majority of JTEs reported not teaching English I or II with an ALT (Table 2). Employing ALTs is expensive, and not all EFL classrooms at the high school level can be supplied with them. However, there may be an additional reason why ALTs are not assigned to team-teach with the majority of JTEs. In the larger study that generated this report, at least ten teachers commented that ALTs in their school were used in oral communication classes, but not for English I or II classes. The impression gained from this is that English I and II were somehow the territory of JTEs. This may mean that these particular JTEs use English I or II courses to teach non-oral English skills for the purpose of preparing students for university exams.

According to Kawakami (1993), under the previous Monbusho Course of Study (1978 to 1993) JTEs had similar attitudes. The older Course of Study provided for English I and II courses ("four [language] skills" courses, p. 19), English IIA, a listening/speaking course; English IIB, a reading course; and English IIC, a writing course. Kawakami claimed that teachers in schools, assuming that English I and II courses were supposed to help students pass university entrance exams, were decoupling 
speaking and listening instruction and simply relegating oral practice to the English IIA course. In current English I and II classrooms, ALTs may not be seen as particularly useful, particularly if ALTs are associated with eikaiwa (oral English used for conversation) and JTEs associate themselves with eigo (non-oral English language as learned from intensive reading) (Law, 1995, pp. 221-222). The distribution of ALTs revealed in this study, then, may be a result of current attitudes about how team teaching is best utilized in EFL education in Japan.

The second research question was: What are the patterns of distribution of ALTs team teaching in English I and II classes according to type of school? There were differences reported by JTEs in the distribution of ALTs according to type of school (public academic, public vocational, and private academic) (Table 3). Refreshingly, a healthy minority of both public academic and public vocational high school teachers reported having at least some ALT contact. This may suggest that there is some approval in these schools of the notion of having ALTs team teach in English I or II classes. It is possible that public high school JTEs (and their local level administrators) are sensitive to recent social trends and Monbusho policies that are arguably leaning towards instruction of English as communication. Because of this trend, JTEs themselves may want to change by developing their skills as teachers, or improving their own oral English skills, in order to meet the changing demands of society. The data also raise the intriguing question of how team teaching activities in vocational schools, schools that are thought to be free of university entrance exam preparation pressure, can be characterized. Clearly, research on EFL instruction in vocational schools should be conducted, something not often done on any topic concerning vocational high school education in Japan (James \& Benjamin, 1988; Okano, 1993), even though fully $26 \%$ of all high school students in Japan attend vocational high schools (Statistics Bureau, 1997, p. 20).

Private academic high school JTEs reported a low level of ALT contact in English I and II classes. Given the data, it may be necessary to view private academic high schools as quite different from high schools in the public sector. The data may be reflecting the fact that private high schools do not participate in the nationally funded JET program. Either the private sector has its own program, or schools hire native English speaking teachers on their own. If ALTs are present in private high schools in any number, they may simply be used to teach courses intended to develop students' oral skills. Finally, private high school JTEs and administrators may feel less sensitivity towards the same social trends and educational policies named above than their public school 
counterparts. For example, Gorsuch (1999a, p. 269) found that the same private academic high school JTEs sampled for this study were more approving of questionnaire item A-4 than public academic and vocational high school JTEs. Item A-4 depicts a yakudoku activity in which students recite their Japanese translations of English texts in English I and II class. The same teachers reported lower levels of approval of CLT activities in English I and II classes than public academic and vocational high school teachers (p. 294). Attitudes towards instruction in private academic high schools may be quite different from those in public high schools. Private academic high schools are likely concerned about attracting students by presenting a successful track record of helping students pass university entrance exams. Whatever the case, if ALTs are associated with CLT instruction, this may account for the pattern of ALT use in private academic high schools found in this study.

\section{ALT Involvement}

What is most remarkable, however, is that the data answering research questions 1 and 2 suggest that ALTs are engaged in team teaching in a surprising number of English I or II classrooms. In public academic and vocational high schools, slightly more than half of responding JTEs reported at least some ALT contact. If ALT involvement in English I and II classes was considered truly inappropriate by these teachers, there might not be so many ALTs teaching in these classes. Longitudinal research is needed to answer the question of whether ALT involvement in English I and II classes is on the rise, or is simply a stable phenomenon over time. Of more central concern is the question of causality: Is the presence of ALTs changing JTEs' attitudes about situations in which team teaching is appropriately used? Or are JTEs changing their attitudes on their own, perhaps through social trends, and then simply requesting ALTs in the English I and II classes as a result of their changing attitudes? This is a question worth investigating further, particularly through extensive interviews with JTEs.

\section{Have ALTs Changed JTEs?}

To restate the third and fourth research questions: Do JTEs' self-reports of English speaking ability differ according to their level of contact with ALTs in English I and II classes, and do JTEs' self reports of their own English learning experiences differ according to their level of contact with ALTs in English I and II classes? These questions deal with JTEs' perceptions of themselves. The third question in particular deals 
with the question raised in the introduction of this report, which was, "Have ALTs changed JTEs?" In terms of JTEs' perceptions of their English speaking ability, I would argue "yes." JTEs who had contact with ALTs in English I and II classes reported their English speaking abilities, as used in class, as being significantly higher than JTEs with limited or no ALT contact (Table 4). I base my argument for causality partly on the observations of Yukawa $(1992,1994)$, who reported that a JTE, through team teaching a reading course with an ALT, progressively used more and more English in class. Through the JTE's contact with the ALT, it is possible that the JTE's confidence in his ability to use classroom English increased, even though Yukawa characterized the JTE as a good speaker of English before his contact with an ALT.

I also base my argument for causality on common sense. If ALTs are not proficient in Japanese, then JTEs and ALTs must communicate in English in order to plan classes and coordinate their instruction while in class. This interaction would necessarily entail the use of classroomspecific and general English, and would give JTEs exposure to the language presented in the lessons through the oral/aural mode, rather than through the written word. This surely would give participating JTEs a real sense of their English abilities. However, there is always the possibility that JTEs chose to work with ALTs because they were already confident in their ability to use English. Nevertheless, I believe previous research and common sense suggest that ALTs are causing positive changes in JTEs' professional abilities. I urge classroom teachers, both ALTs and JTEs, to conduct their own observations along the lines of Yukawa $(1992,1994)$, and to conduct self- and other-interviews to pin down the causality issue, as well as to characterize changes in the professional development of ALTs and JTEs.

The fourth research question addressed JTEs' perceptions of their own language learning experiences and whether contact with an ALT has an effect on those perceptions. The data resulting from this survey were inconclusive (Table 5). Teachers with high ALT contact tended to have lower levels of agreement with the notion that they had learned English through yakudoku than teachers with less or no ALT contact. However, the mean scores of the three groups were not significantly different.

Nonetheless, this intriguing question is still worth asking. It raises several issues. First, if the JTEs in this survey had indicated that their self-perceptions did significantly change with high ALT contact, would it mean that at some point in their teaching careers, those JTEs disassociated themselves from their own learning experiences? This is an 
interesting possibility, and may indicate the direction for further inquiries into the mechanisms of teacher change. Did such teachers see ALT contact as an opportunity for important professional and personal growth? Were they already on the path of self-development, where team teaching with an ALT was simply an available way to meet those JTEs' goals? Most importantly, why did they want to change? Second, is there a group of JTEs who were self-directed enough to learn English through other means, above and beyond the yakudoku universe of their high school and university learning experiences? What would characterize this group? Early overseas experience? Age? There is the final possibility that through contact with ALTs, JTEs' perceptions of their own personal histories took a major shift, even if JTEs were not initially willing to do team teaching with an ALT. Working with an ALT may constitute a transformative event for such teachers. More research is needed.

\section{JTEs and the Current Political Line}

The fifth and final research question was: Does JTEs' level of approval of communicative, ALM, and yakudoku activities differ according to level of contact with ALTs in English I and II classes? JTEs with high ALT contact approved of a communicative information gap activity significantly more than JTEs with less or no ALT contact (Table 6). However, there were no other significant differences in approval of any other activities due to ALT contact. The lack of other significant differences may be for two reasons. First, the activities, as stated, may not have been expressed in ways that teachers can easily apply them to their own practice. That is to say, JTEs may not conceive of and plan their lessons as a series of activities tied to particular approaches to language learning. Instead, they may primarily plan their lessons around vocabulary or grammar structures presented in English I or II textbooks and simply let the lesson flow from that (see Gorsuch, 1999b for a review of English I and II textbooks). Second, JTEs may be feeling beleaguered by recent shifts in educational policy, and may feel reluctant to answer questions about what activities and methodologies they prefer. Therefore, questionnaires may not be the best method of investigating JTEs' approval of activities. Certainly, JTEs' responses to all the activities items in the questionnaire were centered at a rating of mild approval (Table 6), a conservative and cautious place in which to be.

This leaves us with the higher approval of a CLT activity by high-ALTcontact JTEs. There are several reasons why such teachers may approve of the information gap activity. First, teachers who have regular contact with ALTs may find it easier to model CLT pair work activities for stu- 
dents with the help of an ALT. Second, it could be that when an ALT is in the classroom, students (and/or the ALT) expect to do something different from highly controlled ALM and yakudoku activities. Finally, there may be a link with teachers' self-perception of English speaking skill - recall that teachers teaching with ALTs at least once a week rated their English speaking skills higher than teachers who had less or no contact with ALTs (Table 6). Perhaps teachers who have more confidence in their ability to speak English are more likely to approve of A-3, the information gap activity.

\section{Conclusion}

I believe the data presented in this report generally point to the positive effects ALTs have on JTEs. I think we need to view the JET program and the presence of ALTs as a dynamic, if unevenly available, form of in-service teacher education. Whether a causal factor or not, the presence of an ALT is linked with higher JTE reports of classroom-centered English speaking ability and greater approval of a communicative information gap activity. Clearly, ALTs encourage professional and personal growth in JTEs by helping diversify their instructional practice, and stretching their abilities to communicate in English. I believe that ALTs are indeed changing the way English is taught in Japan, and that they are changing it for the good.

I have noted, however, that ALTs are unevenly distributed in English I and II classes in Japanese high schools, perhaps as a result of prevailing attitudes that ALTs should be used for "communication" and "games." I would like to argue here that ALTs, and CLT activities, belong in English I and II classes. English I and II are the most commonly taught classes in high schools, and if Monbusho wants Japanese students to be able to be the "cosmopolitan" and foreign-language-proficient citizens they dream of (Lincicome, 1993), using ALTS and CLT activities in English I and II classes is the best way to reach the greatest number of students. Further, English I and II courses are four-skills courses, and should not be de facto reading/university exam preparation courses. Finally, there is nothing in the course descriptions for English I and II courses that precludes the use of CLT activities. With a minimum of awareness and planning, CLT activities can promote all of the goals and objectives set out in the English I and II course description in The Course of Study (Ministry of Education, Science, and Culture , 1992).

\section{Acknowledgements}

For Dale T. Griffee, who keeps asking questions. I would also like to thank the two JALT Journal reviewers for their comments. 
Greta Gorsuch is an assistant professor of applied linguistics at Texas Tech University, Lubbock, Texas. A former editor of The Language Teacher and co-author in the Impact series (Lingual House), she is interested in testing, teacher and faculty learning, and the effects of educational policies and cultures on teachers' instructional decisions. She can be reached at < greta.gorsuch@ttu.edu>.

\section{References}

Bryant II, W. C. (1956). English language teaching in Japanese schools. The Modern Language Journal, 71 (4), 21-48.

Cohen, D. K., \& Spillane, J.P. (1992). Policy and practice: The relations between governance and instruction. Review of Research in Education, 18, 3-49.

Fowler, F. J. (1993) Survey research methods (2nd ed.). Newbury Park, CA: Sage Publications.

Freeman, D., \& Richards, J. (1993). Conceptions of teaching and the education of second language teachers. TESOL Quarterly, 27 (2), 193-216.

Fuller, B., Snyder, C. W. Jr., Chapman, D., \& Hua, H. (1994). Explaining variation in teaching practices? Effects of state policy, teacher background, and curricula in southern Africa. Teaching and Teacher Education, 10 (2), 141-156.

Gorsuch, G. (1998). Yakudoku EFL instruction in two Japanese high school classrooms: An exploratory study. JALT Journal, 20 (1), 6-32.

Gorsuch, G. (1999a). Exploring the relationship between educational policy and instruction in Japanese high school EFL classrooms. Unpublished doctoral dissertation, Temple University, Tokyo, Japan.

Gorsuch, G. (1999b). Monbusho approved textbooks in Japanese high school EFL classes: An aid or a hindrance to educational policy innovations? The Language Teacher, 23 (10), 5, 7, 8-15.

Gorsuch, G. (2000, March). Analyzing SEM-challenged data: Complex models and reluctant respondents. Poster session presented at the annual meeting of the Language Testing Research Colloquium, Vancouver, Canada.

Gorsuch, G. (2001). Japanese EFL teachers' perceptions of communicative, audiolingual and yakudoku activities: The plan versus the reality. Education Policy Analysis Archives [online], 9 (10), 2-26. Available: http://olam.ed.asu. edu/epaa/v9n10.html

Hatch, E., \& Lazaraton, A. (1991). The research manual: Design and statistics for applied linguistics. Boston: Heinle \& Heinle.

Henrichsen, L. E. (1989). Diffusion of innovations in English language teaching: The ELEC effort in Japan, 1956-1968. NY: Greenwood Press.

Hino, N. (1988). Yakudoku: Japan's dominant tradition in foreign language learning. JALT Journal, 10 (1 \& 2), 45-55. 
James, E., \& Benjamin, G. (1988). Public policy and private education in Japan. New York: St. Martin's Press.

JET program kicks off 12th year. (1998, July 23). The Daily Yomiuri, p. 1.

Kawakami, H. (1993). Factors influencing English education in Japanese high schools: A survey of teacher perceptions. Unpublished master's thesis, Brigham Young University.

Kennedy, M. (1989). Policy issues in teacher education. (ERIC Document Reproduction Service No. ED326538)

Law, G. (1995). Ideologies of English language education in Japan. JALT Journal, 17 (2), 213-224.

Lincicome, M. (1993). Nationalism, internationalization, and the dilemma of educational reform in Japan. Comparative Education Review, 37 (2), 123151.

Lortie, D. C. (1975). Schoolteacher: A sociological study. Chicago: University of Chicago Press.

MacDonald, M. A., \& Rogan, J. M. (1990). Innovation in South African science education (part 2): Factors influencing the introduction of instructional change. Science Education, 74 (1), 119-132.

McConnell, D. L. (1995). Japan JETs international: Implementing innovations in educational policy. In J. D. Montgomery \& D. A. Rondinelli (Eds.), Great policies: Strategic innovations in Asia and the Pacific basin. (pp. 75-97). Westport, CT: Praeger.

Ministry of Education, Science, and Culture. (1992). The course of study for senior high school: Foreign languages (English). Tokyo: Author.

Montero-Sieburth, M. (1992). Models and practice of curriculum change in developing countries. Comparative Education Review, 36 (2), 175-193.

Okano, K. (1993). School to work transition in Japan. Clevedon, UK: Multilingual Matters Ltd.

Rea, L. M. \& Parker, R. A. (1992). Designing and conducting survey research. San Francisco, CA: Jossey-Bass Publishers.

Schmidt, W., Porter, A., Floden, R., Freeman, D., \& Schwille, J. (1987). Four patterns of teacher content decision-making. Journal of Curriculum Studies, 19 (5), 439-455.

Shimahara, N. (1995). Teacher education reform in Japan: Ideological and control issues. In N.K. Shimahara \& I. Z. Holowinsky (Eds.), Teacher education in industrialized nations: Issues in changing social contexts (pp. 155-193). NY: Garland Publishing, Inc.

Statistics Bureau (1997). Japan statistical yearbook 1997. Tokyo: Government and Coordination Agency, Government of Japan.

Stevenson, D. L., \& Baker, D. P. (1991). State control of the curriculum and classroom instruction. Sociology of Education, 64 (1), 1-10. 
Vogt, W. P. (1999). Dictionary of statistics \& methodology (2nd ed.). Thousand Oaks, CA: Sage Publications.

Wada, M. (1994). Team teaching and the revised course of study. In M. Wada \& T. Cominos (Eds.), Studies in team teaching (pp. 7-16). Tokyo: Kenkyusha.

Wada, M., \& Cominos, T. (1994). Language policy and the JET program. In M. Wada \& T. Cominos (Eds.), Studies in team teaching (pp. 1-6). Tokyo: Kenkyusha.

Yukawa, E. (1992). Team teaching and changes in teaching routines. The Language Teacher, 18 (11), 9, 11, 13.

Yukawa, E. (1994). Team teaching and changes in teaching routines in a Japanese high school reading classroom. In M. Wada \& T. Cominos (Eds.), Studies in team teaching (pp. 42-60). Tokyo: Kenkyusha.

(Received October 22, 2001; Revised December 28, 2001)

\section{Appendix}

This questionnaire is designed for teachers who are currently teaching English I and/or English II. If you are not teaching these courses this year, please give this questionnaire to a colleague who is teaching English I and/or English II this year. Thank you!

Please read the activity descriptions below and write a circle or check in the blank that best describes your level of agreement. Please consider each activity carefully, and let your response reflect your true impression about the appropriateness of the activities for your current English I or II classes. If you choose "5" for example, this means you would be strongly willing to use the activity in your class. If you choose " 1 ", this means, you would not be at all willing to use the activity. Please choose only one response.

A-1. The teacher asks students to translate English phrases or sentences into Japanese as preparation for class.

I think the above is an appropriate activity for my English I or English II classes: strongly agree___ agree___ don't know __ disagree strongly disagree 5 43 2 1

A-2. The teacher has students look at a page that has a "picture strip story." Students can uncover only one picture at a time. Before uncovering the next picture, the students predict, writing the prediction in English, what will happen in the next picture. Students can then look at the next picture to confirm or disconfirm their predictions. 
I think the above is an appropriate activity for my English I or English II classes: strongly agree agree don't know disagree strongly disagree
5
4
3
2
1

A-3. The teacher has the students work face to face in pairs. One student sees a page that has some missing information. The other student sees a different page that has that information. The first student must ask questions in English to the other student to find the missing information.

I think the above is an appropriate activity for my English I or English II classes: strongly agree agree don't know disagree strongly disagree

5

4

3

2

1

A-4. The teacher asks students to translate English phrases or sentences into Japanese in preparation for class. Then in class, the teacher calls on individual students to read their Japanese translation of an English phrase or sentence, and the teacher corrects it if necessary and gives the whole class the correct translation with an explanation.

I think the above is an appropriate activity for my English I or English II classes: strongly agree agree don't know disagree strongly disagree_

A-5. The teacher has students chorally repeat word pairs such as sheep/ship and leave/live.

I think the above is an appropriate activity for my English I or English II classes: strongly agree agree don't know disagree strongly disagree
5
4
3
2
1

A-6. The teacher has students memorize and practice a short English sentence pattern. The teacher then gives the students a one word English cue and has the students chorally say the sentence pattern using the new word.

I think the above is an appropriate activity for my English I or English II classes: strongly agree agree don't know

disagree strongly disagree
5
4
3
2 1

A-7. The teacher pairs off students. Then the teacher asks the students to write a letter in English to their partner.

I think the above is an appropriate activity for my English I or English II classes: strongly agree agree don't know disagree. strongly disagree

5

4

3

2

1

A-8. The teacher has students memorize an English dialog and then has the students practice the dialog together with a partner.

I think the above is an appropriate activity for my English I or English II classes: strongly agree agree don't know disagree strongly disagree_ 
A-9. The teacher has pairs or small groups of students ask each other and then answer questions in English about their opinions.

I think the above is an appropriate activity for my English I or English II classes: strongly agree agree don't know disagree strongly disagree

5

4

3

2 1

A-10. Students read a sentence in Japanese, and then see an equivalent English sentence below where the words have been scrambled up. The students must then rewrite the English sentence in the correct order suggested by the Japanese sentence.

I think the above is an appropriate activity for my English I or English II classes: strongly agree agree don't know disagree strongly disagree

5

4

3

2

1

A-11. On one page students see a picture. Underneath the picture are several short English stories. Students have to choose which story they think best matches the picture.

I think the above is an appropriate activity for my English I or English II classes: strongly agree agree don't know disagree strongly disagree

A-12. On a page, students see an English paragraph in which the sentences have been scrambled. The teacher then asks the students to put the sentences into order so the paragraph makes sense.

I think the above is an appropriate activity for my English I or English II classes: strongly agree agree don't know disagree strongly disagree
5
4
3
2
1

A-13. What activity do you feel is most effective for your students in your English I or II class? Please write a brief description here: (Optional)

Please answer the following questions by writing a check next to the most correct answer. Choose only one response.

B-1. How many years have you been teaching in high school?

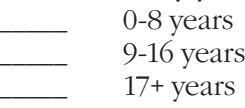

B-2. What kind of high school are you currently teaching in? public academic high school public commercial or industrial high school public night high school private academic school

B-3. Are you currently teaching English I or English II with an ALT (Assistant Language Teacher)? 
Yes, at least once a week.

Yes, but less than once a week.

No, I do not teach English I or English II with an ALT.

Please read the sentences below and write a check in the blank that best describes your level of agreement. Choose only once response.

C-1. My English speaking ability is good enough for me to use in class. strongly agree agree don't know disagree strongly disagree_
5
4
3
2
1

C-2. As a student I studied English primarily through translating English stories, essays, or literary works into Japanese.

strongly agree agree don't know disagree strongly disagree_
5
4
3
2
1

C-3. I think the pace we have to teach English at my high school is: $\begin{array}{ccccc}\text { much too fast___ fast__ about right__ slow__ much too slow__ } & \text { _ } & 3 & 2 & 1\end{array}$

C-4. The average size of my English I or English II classes is:

$\begin{array}{ccccc}\text { over } 50 & 40-49 & 30-39 & 20-29 & \text { below } 19 \\ 5 & 4 & 3 & 2 & 1\end{array}$

Please read the sentences below concerning your current instruction in English I and II classes and write a check in the blank that best describes your level of agreement. Choose only one response.

D-1. The Monbusho guidelines for English I and English II influences my classroom practice.

strongly agree agree____ don't know disagree strongly disagree - 5 5 4 3 2 1

D-2. College and university entrance exams influence my classroom practice. strongly agree agree don't know disagree strongly disagree 5 43 32 1

D-3. The textbook my students are using influences my classroom practice. strongly agree don't know disagree strongly disagree_ 5 4 3 2 1

D-4. The teaching license program I completed at university influences my current classroom practice. strongly agree agree don't know disagree strongly disagree_ 
D-5. In-service teacher education specifically designed for English teaching offered by my prefectural or municipal board of education influences my classroom practice.

strongly agree agree

don't know

disagree

strongly disagree_

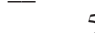

5

4

3

2

1

In-service teacher education for English teaching is not available from the Board of Education for me.

D-6. The way I learned English as a student influences my current classroom practice.

strongly agree agree don't know disagree strongly disagree_ 5

4
3

2 1

D-7. My English teaching colleagues influence my classroom practice. strongly agree agree don't know disagree strongly disagree 5 4 3 2 1

D-8. The principal at my school influences my classroom practice. strongly agree agree don't know disagree strongly disagree

4

3

2 1

D-9. Teaching courses I have taken privately influence my current classroom practice.

strongly agree agree don't know disagree strongly disagree 5

4

3

2

1

I have not taken teaching courses privately.

D-10. My membership in a private academic organization influences my classroom practice.

strongly agree agree don't know disagree strongly disagree

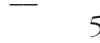
5

$$
4
$$

$$
2
$$

I am not a member of an academic organization.

D-11. The English I and English II syllabus used at my school influences my classroom practice.

strongly agree agree don't know disagree strongly disagree 5

D-12. The number of students in my English I or II classes influences my classroom practice. (i.e., Would you teach differently if your classes had many students or few students?) 
strongly agree agree

don't know

disagree strongly disagree 5 4 3 2 1

D-13. The ALT I teach English I or II with influences my classroom practice. strongly agree agree don't know disagree strongly disagree_

- 5
5 4 3 2 1

I do not currently teach English I or English II with an ALT.

D-14. The expectations of my students' parents influences my classroom practice. strongly agree agree don't know disagree strongly disagree

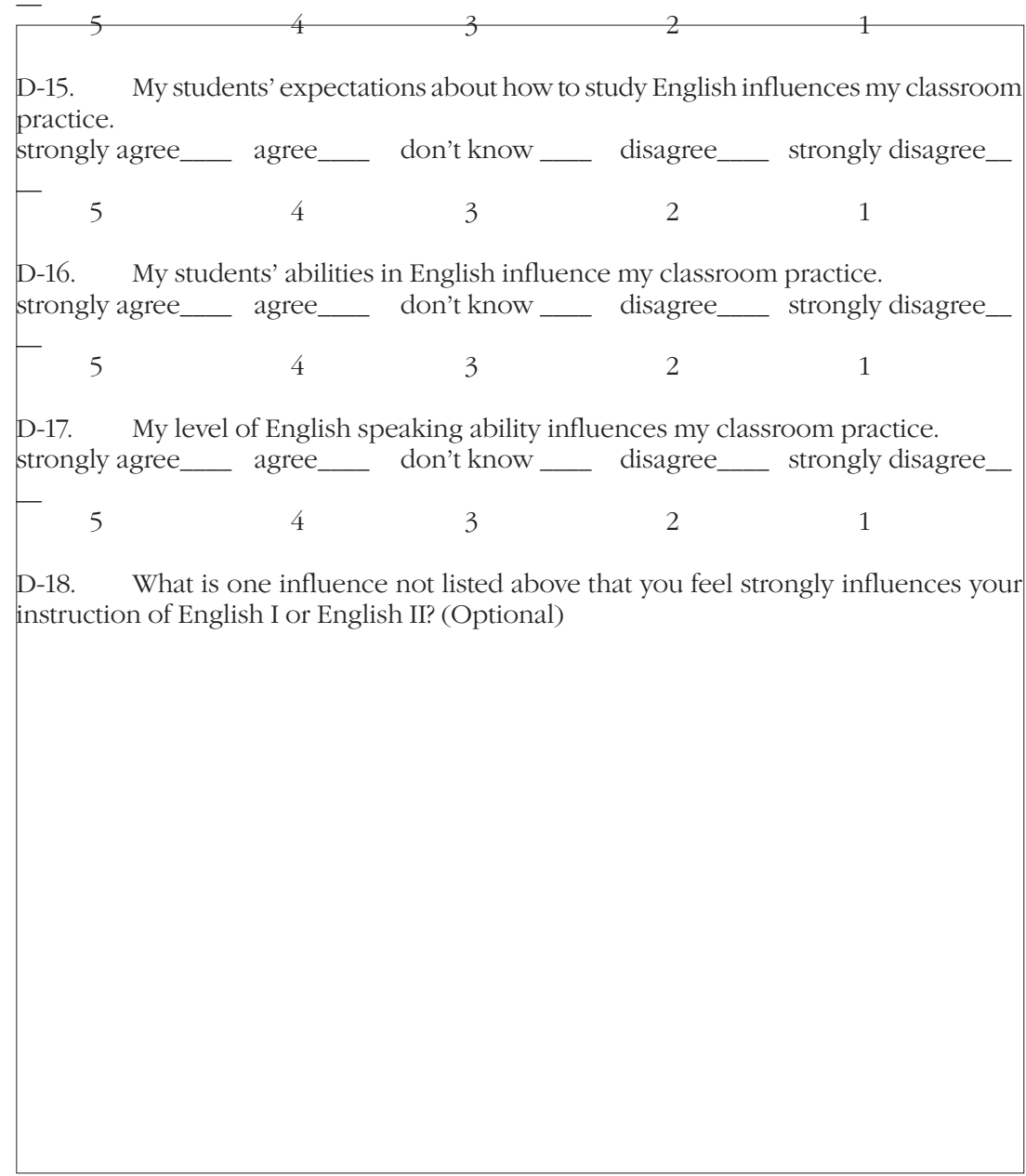

